\title{
Die konsep vrou: 'n Feministiese historiografie oor die verhouding tussen die vroulike en die manlike geslag
}

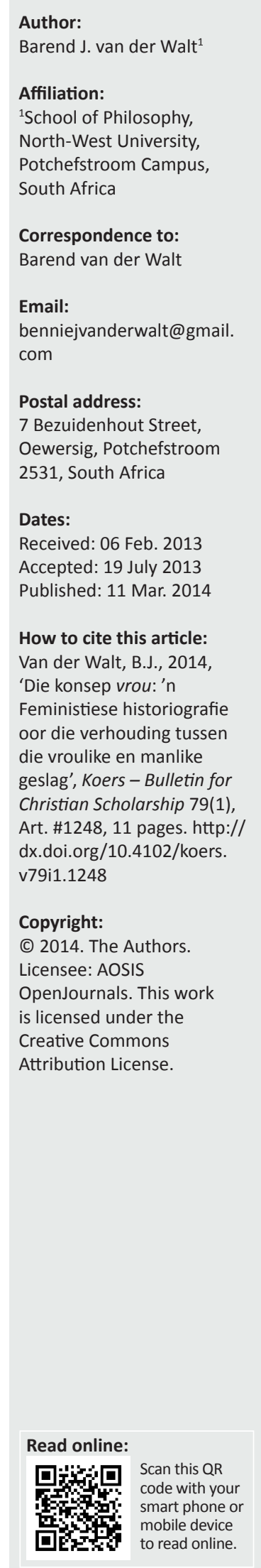

Hierdie artikel analiseer die vooronderstellings waaruit die geskiedenis van die konsep vrou in die feministiese filosoof Prudence Allen se belangrike werk, The concept of woman, filosofies benader word. Volgens 'n ideëgeskiedenismetode ondersoek sy die visies van 60 manlike en vroulike Westerse denkers ten opsigte van die vrou gedurende 750 v.C. tot 1250 n.C. Sy bespreek ook drie basiese modelle vir die verhouding tussen die vrou en die man, naamlik geslagtelike eenheid, polariteit en komplementariteit. Twee van die artikelskrywer se belangrikste probleme met haar filosofiese historiografie is eerstens dat sy nie duidelik genoeg aantoon hoe die verskillende onties-antropologiese uitgangspunte op die mens die uiteenlopende visies op die twee geslagte bepaal nie. Tweedens soek sy na die norm vir die relasie tussen die twee geslagte op subjektivistiese wyse in hulle verhoudings self, in plaas van in 'n maatstaf buite die verhoudings. Haar eie voorkeur vir 'n komplementêre verhouding word ook bevraagteken. Verder blyk dit dat sy die onderskeid tussen natuurgenade en filosofie-teologie nie konsekwent op die geskiedenis kon toepas nie. Met die oog op verdere besinning, word ter afsluiting die standpunte van enkele kontemporêre Protestantse denkers oor die onderwerp vermeld. Verder word 'n opvolgartikel in die vooruitsig gestel waarin aangetoon sal word dat 'n konsekwent probleem-historiese metode van wysgerige historiografie antwoorde kan bied op die twee hoofgebreke van Allen se andersins boeiende en baanbrekende studie.

The concept woman: A feminist historiography of the relation between female and male. This article analyses the presuppositions underlying the feminist philosopher Prudence Allen's important book, The concept of woman, on the history of the idea of woman and women's relation to the other sex. Following the method of the history of ideas, she investigates the viewpoints of about 60 male and female western thinkers during 750 BC - AD 1250. She distinguishes three basic models in the relation between female and male, viz. gender unity, polarity and complementarity. The writer of his article, however, highlights apart from other queries, two major problems with her historiography. Firstly, she does not indicate clearly enough how different ontic-anthropological philosophical starting points determined the differing viewpoints on the two genders. Secondly, instead of accepting a norm from outside, she looks for a directive on the relation between male and female (in a subjectivist way) in the relation itself. Such an approach is the consequence of her dualistic division between a supposed neutral philosophy and Christian theology. She also does not succeed to apply her nature-grace and philosophy-theology distinction consistently in her review of history. Furthermore, Allen's preference for the idea of complementarity is questioned. To stimulate further reflection, a few contemporary protestant views on the same issue are pointed out. In conclusion a follow-up contribution is envisaged which will indicate that a consistent problem-historical method of philosophical historiography may provide answers to the two main shortcomings identified in Allen's otherwise captivating and ground-breaking study.

\section{Oriëntering}

Vir 'n aanvang is dit gewens om drie redes te noem ter motivering van die blywende aktualiteit van 'n ondersoek soos hierdie. 'n Mens moet daarop let dat hierdie verkenning filosofies van aard is en daarom moet die beperkings wat hierdeur daaraan opgelê is, vermeld word. Belangrike terminologiese verduidelikings vra ook die aandag in hierdie artikel.

\section{Blywende aktualiteit}

Eintlik het 'n studie oor die konsep vrou (of man) nie motivering nodig nie. Van Leeuwen (1993) skryf:

There is not a person alive who does not participate in shaping and being shaped by gender roles and relationships, and there is arguably not a single aspect of our lives that is not influenced by the results of that shaping. Child-raising practices, education, language, law, health care, dress, work, worship - these 
and all other areas of our lives are variously nuanced, enriched, and distorted by our assumptions about gender and the practices that result. (bl. xv)

Voeg by hierdie uitspraak nog die skrywer se eie belangstelling (cf. Van der Walt 1987, 2006a, 2006b, 2006c, 2006d, 2011) en verdere motivering vir die bespreking van sodanige onderwerp sou byna oorbodig gewees het. Drie belangrike addisionele redes word egter hier vermeld.

\section{Vele vrae is nog steeds onbeantwoord}

Ten eerste behoort enige persoon wat 'n artikel oor die konsep vrou in die Antieke Griekse en Middeleeuse denke skryf, seker die redes te bied waarom die skrywer so 'n antikwaries-argeologiese aktiwiteit vandag nog as belangrik beskou. Waarom nie liewer 'n artikel skryf oor die hedendaagse postmodernistiese feminisme of homoseksualisme nie?

Die antwoord op hierdie vraag is dat die kwessie van geslagtelikheid nie 'n onderwerp is waaroor eers vanaf ons eie tyd besin is nie. Volgens Allen (1985) het die Antieke Grieke alreeds drie basiese teorieë daaromtrent gehuldig, naamlik polariteit, eenheid en komplementariteit tussen die man en die vrou. ('n Verduideliking van hierdie drie teorieë volg later.) Indien 'n mens Chanter (2006), James (2005), Verkerk (1997) en Storkey (2001) raadpleeg, kom jy tot die gevolgtrekking dat die verskillende moderne feministiese stromings nog steeds met naastenby dieselfde probleme worstel. Dit blyk uit die volgende vereenvoudigde oorsig.

Tot ongeveer 1950 is veral die polêre verhouding tussen die vroulike en die manlike geslag deur die feministe beklemtoon. Vanaf ongeveer 1960-1980 verskuif die klem na eenheid of gelykheid. In die postmoderne feminisme daarna word beklemtoon dat vroue hulle eiesoortige identiteit - in teenstelling tot dié van mans - self moet (re)konstrueer. Dit wil dus lyk asof 'n mens hier met 'n oeroue, maar steeds onopgeloste probleem te make het waarvoor slegs 'n beperkte aantal oplossings logies moontlik is. Die vraag is egter watter een die korrekte is.

\section{Weinig besinning in Protestantse kerke en teologie}

Alhoewel een van die keurders van hierdie artikel se kommentaar was dat dit deurspek is van verouderde taalen denkpatrone wat vreemd klink binne die onlangse en kontemporêre feministiese diskoers, was die persoon wel ten gunste van die publikasie daarvan, aangesien dit 'n verwaarloosde onderwerp binne die reformatoriese tradisie is. My tweede motivering vir die artikel was dus spesifiek hierdie blindekol in my eie tradisie.

Waarom moet baie vroue nog steeds met ' $n$ minderwaardige rol in verskeie Protestantse kerke tevrede wees? Van Leeuwen (1990:11) bekla byvoorbeeld die feit dat Calvinistiese geleerdes dit nog so selde gewaag het om die vraagstukke rondom geslagtelikheid te bestudeer. Hulle het hulle nadenke beperk tot ' $n$ besinning oor die kwessie van die hoofskap of gesag van die man oor die vrou - veral in die kerk - terwyl die groot hoeveelheid sekulêre, filosofiese en ander teologiese lektuur oor seksualiteit en geslagtelikheid by hulle verbygegaan het. Van Leeuwen (1993:13) praat selfs van 'Protestantism's preoccupation with the ordination of women'. Hulle standpunte (oor manlike gesag en mag) kan nie biblisisties met 'n blote beroep op Skriftekste opgelos word nie.

Biblisisme beteken dat 'n mens jou eie voorafingenome standpunt oor ' $n$ aangeleentheid agtereenvolgens eers in die Skrif inlees (eisegese) om dit daarna - nou egter met 'n goddelike sanksie - weer daaruit te lees (eksegese). Op so 'n wyse kan 'n mens (soos in die geval van die Algemene Sinode van die Gereformeerde Kerk in Suid-Afrika in Januarie 2012) die Woord van God volgens die eie standpunt laat buikspreek en sowel 'n standpunt vir die vrou in die kerklike ampte as een daarteen as skriftuurlik verdedig.

Wat Landman (1984:23) destyds geskryf het, naamlik dat die debat oor vroue in Suid-Afrika nog nie verder beweeg het as die vraag of die vrou as ouderling of predikant mag dien nie, het wel sindsdien verander, maar helaas nog nie in byvoorbeeld my eie kerk (die Gereformeerde Kerk) nie.

Van ouds af sit die gereformeerde tradisie vas in 'n seksistiespaternalistiese beskouing, soos duidelik blyk by die volgende twee vaders daarvan.

\section{Johannes Calvyn (1509-1564)}

In haar resente proefskrif toon Alida Sewell (2011) aan hoe Johannes Calvyn (net soos Aurelius Augustinus, 354-430 v.C.) se sterk Platoniserende antropologiese visie op die menslike liggaam ook sy beskouings oor die vrou bepaal het. Hy interpreteer die Bybeltekste sodanig dat dit manlike meerderwaardigheid en vroulike onderdanigheid, asof in ooreenstemming met die 'natuur', goedkeur (vgl. Sewell 2011:178). Calvyn roep vroue dus op om nie teen hulle eie natuur buite die huwelik en die huis op te tree nie. Vroue is die swakker geslag, geneig om te klets, jaloers te wees en hulle kan nie hulle emosies onder redelike beheer hou nie (Sewell 2011:185) - so word die ou bekende stereotipes opgerakel!

Alhoewel Calvyn die koninkryk van God as iets geesteliks nie van hierdie wêreld nie - beskou, bring selfs dit by hom ook geen verandering ten opsigte van die posisie van die vrou nie:

The headship of male over female continues for him to be a creational given, and any inequality that this entails is not set aside by the redemptive implications of being in Christ ... His insistence of the inviolability of the natural order of the subordination of women to men ... secures the bolt to the door of the patriarchal prison for women. (Sewell 2011:190)

Die sestiende-eeuse Reformasie verlos die vrou wel uit die klooster (as heilige) en die kroeg (as prostituut), net om haar weer in die kamer (as vrou), aan kinders (as moeder), in 
die kombuis (as huisvrou) en in die kerk (as tweederangse gelowige) vas te kluister.

\section{Abraham Kuyper (1837-1920)}

Kuyper ([1913] 1932) se visie op die vrou toon 400 jaar later nog geen verbetering op dié van Calvyn nie. In sy werk, De erepositie der vrouw, kry sy glad nie 'n ereposisie nie. Hy gaan so ver as om te beweer dat die man en die vrou volgens hom twee soorte mense is met totaal verskillende nature. Die rede daarvoor is eerstens hulle fisieke voorkoms (Kuyper [1913] 1932:39, 40). Die swakker vroulike liggaam is onder andere juis so gebou sodat sy kinders kan hê. Tweedens is vroue ook psigies heeltemal anders as mans (vgl. Kuyper [1913] 1932:23, 35, 41). Vroue is emosioneel en beskik nie oor die intellektuele vermoëns van mans nie. In die derde plek is die vroulike geslag dus eintlik ongeskik vir die openbare lewe (Kuyper [1913] 1932:49).

Agter so'n beskouing skuil 'n hiërargiese visie op geslagtelike verskille waarvolgens die vroulike geslag op elke punt heel onderaan die hiërargie verskyn en dus as minderwaardig bevind kan word. Kuyper pretendeer op die oog af wel om seksuele en ander verskille te erken, maar wis dit telkens weer uit deur slegs een vorm van menswees, naamlik manlikheid, tot die norm van menswees te verhef en vroue se andersheid as minderwaardigheid te verstaan.

Van Leeuwen (2013) het 'n deeglike studie van hierdie werk van Kuyper gemaak waarin sy onder andere aandag skenk aan die historiese agtergrond daarvan, die inhoud saamvat, op die voortgesette invloed daarvan wys asook kritiek daarop lewer. (Die teks is ook reeds in Engels vertaal, maar blykbaar nooit gepubliseer nie - vergelyk Van Leeuwen 2013:423, voetnoot 3.)

\section{Reformatoriese filosofie is ook nie van hulp nie}

'n Derde rede vir hierdie ondersoek is dat 'n mens, afgesien van die gereformeerde teologiese tradisie, ook deur die latere reformatoriese filosofie teleurgestel word. Janet Wesselius (1997:61) skryf tereg van een van die vaders van hierdie rigting, Herman Dooyeweerd (1894-1977): '... being an early twentieth-century European, he never discussed gender in his philosophical arguments ...'. Dieselfde sou van die twee ander vaders van die reformatoriese filosofie, Dirk Th. Vollenhoven (1892-1978) en Henk Stoker (1899-1993) gesê kan word.

'n Mens sou in hulle verdediging kon aanvoer dat dit in hulle tyd nog nie so 'n aktuele vraagstuk was nie. Terselfdertyd kan hulle stilswye egter as bewys van hulle instemming met die status quo beskou word.

\section{'n Filosofiese benadering}

Vroulike en manlike geslagtelikheid kan uit verskillende wetenskaplike hoeke, byvoorbeeld psigologiese, biologiese, teologiese en nog ander hoeke, benader word. Vir'n voorbeeld van eersgenoemde perspektief, vergelyk Buijtendijk (1975) en vir 'n algemene oorsig, vergelyk Chanter (2006).
Soos reeds gesuggereer, wil hierdie bydrae egter probeer deurdring na die filosofiese grondslae van die verskillende 'oplossings' vir die visie op en die verhouding tussen die twee geslagte. Die artikel wil die dieper ontologiese perspektiewe op die werklikheid en veral die mens probeer blootlê wat aan die verskillende standpunte ten grondslag lê.

\section{Twee basiese vrae}

Twee eenvoudige maar belangrike vrae behoort deur elke mens - veral die filosoferende homo sapiens - gestel te word. Die eerste is: Wie is ek? (Is ek 'n vrou of 'n man? Hoe verskil ons van mekaar en waarin kom ons ooreen?) Dit is die ontiese of strukturele probleem. Die tweede basiese vraag is: Hoe behoort ek te dink en te lewe as geslagtelike wese? (Dit sluit ook my verhouding met die teenoorgestelde geslag in.) Hierdie tweede fundamentele vraag gaan oor die normatiewe rigting van 'n mens se lewe, die direksionele probleem.

Hoewel 'n mens die twee vrae en hulle antwoorde kan onderskei, mag hulle egter nie geskei word nie. Die volgende vlugtige oorsig verduidelik hoe die antwoorde op hierdie vrae in die verloop van die Westerse denke oor geslagtelikheid vervleg is.

\section{Groeiende subjektivisme}

Tot ongeveer die Middeleeuse denke is die ontiese faset van menswees nog sterk benadruk. Die mens se strukturele kant, dit wil sê die man en die vrou se geslagtelikheid, is beklemtoon en is as min of meer onveranderlik beskou. Hierdie denkpatroon het alreeds in die Griekse denke voorgekom, terwyl die Christelike Middeleeue bowendien goddelike sanksies daarop kon plaas. Mense, vroue en mans, het 'n eie wese (natuur) van God ontvang (essensialisme genoem), wat ook hulle onderlinge verhouding moes bepaal.

In die tyd ná die Middeleeue (breedweg, die 'moderne tyd') verdwyn God en sy verordenings al hoe meer uit die gesigsveld. Nuwe norms vir leer en lewe moes dus gevind word - ook by feministiese denkers.

Die feministiese denke kan op baie maniere in verskillende stromings onderverdeel word (vgl. bv. Ackerman 1998; Keane 1998; Landman 1984, 1998; James 2005; Chanter 2006). Storkey (2001) se indeling word hier gebruik. Sy onderskei tussen drie normatiewe stromings. Aanvanklik (tot ongeveer 1950) word ook binne die feminisme gedink dat dit die biologiese verskille is wat vroulikheid bepaal. As geskape of natuurlike toestand determineer dit geslagtelikheid op 'n essensialistiese manier. (Storkey noem dit die pre-moderne visie.) Later (ongeveer 1960-1980) verskuif die klem vanaf die biologies-seksuele natuur van die vrou (haar seks) na vroulike geslagtelikheid (haar gender), na die kulturele omgewing wat vrouwees sou bepaal. (Storkey noem dit die moderne standpunt.) Simone de Beauvoir (1964; vgl. ook 1962 en 1965 oor haar eie lewensgeskiedenis) redeneer byvoorbeeld dat iemand nie as 'n vrou gebore word nie, maar dat sy deur haar kulturele omgewing 'n vrou gemaak word. Binne die postmoderne feminisme (ná 1980) neem 
hierdie subjektivistiese normatiwiteit nog 'n verdere stap. Hedendaagse feministe verwerp die premoderne en moderne benaderings en redeneer dat vroue hulle eie geslagtelikheid anders as dié van die man - op 'n outonome wyse self moet konstrueer en rekonstrueer. In teenstelling met De Beauvoir, skryf die postmodernistiese feminis, Luce Irigaray, dat sy wel as vrou gebore is, maar dit ook nog moet verwerklik (vgl. Olthuis 2005:72).

\section{Postmoderne relativisme}

Christelike feministiese denkers sien in hierdie postmoderne feminisme tereg 'n groot gevaar van relativisme:

... postmodern feminist risks undercutting the entire feminist project. For if there is only diversity and pluralism, who can dare to say what is 'right' and 'true' for all women? If all thought and values are relative ... who can ever say that oppressive patriarchy ... is any less valid than a feminist vision of mutuality and gender justice? (Van Leeuwen 1993:69)

Storkey (2001) voeg hierby:

... the weaknesses of postmodernity are centered inevitably on its relativism, for we are compelled to ask, 'Where do we deconstruct from?' What is our starting point? Since postmodernity has no foundational starting point, it always has to deconstruct from a position of deconstruction. And when constructs are relativized, it is from a position of relativism. (bl. 125)

Sy vervolg met skerp immanente kritiek:

But this leaves a large internal problem with the formulation of the postmodern position. What does it mean to say, 'Everything is relative'? If the statement itself has merely a relative status, it cannot be in any sense binding, for it is not making any claim to truth. But if 'everything is relative' has an absolute status and claims truth for itself, then it negates its own formulation. Yet, though the claim to relativism cannot be articulated, it still tries to be prescriptive. It continues to insist that nothing is fixed, and we may not make categorical statements. In fact, relativism is at best an absolutization of indifference. (Storkey 2001:125-126)

In die loop van hierdie artikel sal verder op bogenoemde twee belangrike filosofiese vrae (die strukturele en die normatiewe) ingegaan moet word.

\section{Beperking}

As gevolg van die beperkte lengte van die artikel word hier slegs een hoofbron (Allen 1985) gebruik waarop deurlopende kommentaar gegee word. Die werk van Allen is wel nie resent nie en ook vanuit 'n Katolieke perspektief geskryf. Dit is egter die enigste werk van gehalte wat die skrywer kon vind waarin die konsep vrou oor 'n lang periode (vanaf die antieke Grieke tot die Middeleeue) volgens 'n bepaalde filosofiese historiografie nagevors is. Sover sy kennis strek, bestaan daar nie iets soortgelyks binne Protestantse kringe nie. Bowendien was daar in die verlede nie soveel verskil tussen die Katolieke en Protestante se eeu oue visies ten opsigte van hierdie saak nie.

As sekondêre bronne word daar ook van soveel moontlik vroulike skrywers gebruik gemaak, veral die enkeles wat vanuit ' $\mathrm{n}$ min of meer reformatoriese perspektief hulle stemme laat hoor het.

\section{Terminologie}

'n Laaste verduideliking gaan oor die terminologie wat op hierdie terrein gangbaar is.

\section{Drie begrippe}

Van Leeuwen (1990:19) onderskei seks en geslagtelikheid (gender). Eersgenoemde gaan oor die suiwer biologiese fasette van die twee geslagte, soos gene, hormone en breinanatomie. Laasgenoemde dui op aangeleerde, gesosialiseerde verskille in hulle gedrag. ' $n$ Derde begrip, seksualiteit, omskryf sy as '... that complex of feelings, thoughts and behaviours that constitutes sexual attraction and arousal in each of us, from its first stirrings to its final resolution' (Van Leeuwen 1990:210).

Storkey (1995) beskou hierdie onderskeid ook as belangrik:

... sexuality is the way we relate to ourselves and others subjectively in the biotic sphere, and gender is the way our sexuality is shaped, directed and positivised within the social, historical, aesthetic, economic and even pistical. It prevents us from confusing cultural responses to male-female relations with the creational givenness of our sexual humanity. (bl. 87)

\section{Versigtigheid gewens}

Veral as gevolg van die hedendaagse neiging om alles tot seks te reduseer, is hierdie onderskeid belangrik. In 'n latere teks waarsku Storkey (2001) egter teen 'n te rigiede onderskeid tussen seksualiteit, naamlik as iets deur God geskape, en geslagtelikheid as iets kultureels, wat ons self volgens die heersende kultuur skep:

... if we believe in a God who has created a normative structure for relationships, we have to believe in a God who is as interested in our gender as in our biology, for the way we shape our gender is also part of our human response before God. (bl. 128)

Allen (1985:xx) wys verder daarop dat die onderskeid tussen seks(ualiteit) en geslagtelikheid (gender) eers ongeveer vanaf die sewentigerjare van die vorige eeu algemeen gebruiklik geword het. Teen die laat tagtigerjare is die twee begrippe onder postmodernistiese invloed van mekaar geskei. Sy stem ook saam met Storkey dat die onderskeid seksualiteitgeslagtelikheid tot 'n tweedeling in die mens kan lei, terwyl sy self die mens as 'n eenheid wil sien. Sy vervang nogtans die woord sex wat sy in 'n vroeëre uitgawe van haar boek gebruik, met gender in die latere verwerking daarvan.

\section{'n Eie perspektief}

Om te voorkom dat die mens slegs onder twee fasette (seksualiteit en geslagtelikheid) beskou word, maak die artikelouteur die volgende voorstel in ooreenstemming met 'n breër reformatoriese antropologie. Die ganse mens is as geslagtelike wese geskape. Die mees basiese fasette van die mens is die getalsmatige, ruimtelike, fisiese en biologiese noem dit seks. Elke mens belewe en positiveer of konkretiseer die eie geslagtelikheid egter op 'n eie, unieke wyse binne die 
talle ander fasette van die eie menswees: die psigiese, logiese, historiese, taalgebruiks-, sosiale, ekonomiese, juridiese, estetiese, etiese en godsdienstige fasette.

Na hierdie lang inleiding word die hoofbron nou onder die loep geneem.

\section{Allen oor die konsep vrou}

Agtereenvolgens word aandag gegee aan die volgende aspekte: Allen se hoofprobleem; haar filosofiese metode; feministiese benadering; ideëgeskiedenis; drie basiese idees oor die verhouding tussen die twee geslagte; die antropologiese wortels van die verskillende idees; haar eensydige klem op verhoudings; die feit dat geslagtelike komplementariteit as norm beskou word; en ten slotte die vraag wat presies Allen met geslagtelike komplementariteit bedoel.

\section{Die sentrale probleem}

Verskil die man en die vrou van mekaar? Indien wel, waarin verskil hulle presies? Beteken die verskil ook dat daar 'n minderwaardigheid van die een teenoor die ander is, of is die twee geslagte dalk gelyk, dieselfde, bloot mense? Aangesien hulle tog duidelik ook verskillend is, waarin lê dan hulle ooreenkoms of enersheid?

Sulke vrae lei tot verskillende teorieë of modelle oor geslagtelikheid. Indien die verskille in geslagtelikheid vir iemand nie belangrik of relevant is nie, lei dit maklik tot 'n teorie van geslagtelike gelykheid of enersheid (ook unisex genoem). Word die verskille as belangrik beskou en ook positief waardeer, is die gedagte van komplementariteit voor die hand liggend - die verskille behoort mekaar (soos die twee teenoorgestelde pole van magnete) aan te vul. Indien die verskille oorbeklemtoon word, kan dit egter ook negatief geïnterpreteer word as geslagtelike polariteit, waarvolgens die een geslag (gewoonlik die vroulike) dan as minderwaardig teenoor die ander beskou word en die een moet probeer om oor die ander te heers.

'n Mens sou die voorafgaande die sentrale probleemkompleks by Allen (1985) kon noem. Anders as wat die titel van die boek suggereer, gaan dit vir haar dus nie net om die konsep vrou nie, maar oor die verhouding tussen die twee geslagte. As professor in filosofie aan die Concordia Universiteit in Montreal, Quebec in Kanada, vertel Allen die boeiende verhaal van die geskiedenis van die konsep, vrou, vanaf 750 v.C. tot 1250 n.C. (In Allen 2002 word hierdie verhaal tot 1500 n.C. voortgesit.) Hierdie artikel wil nie 'n bespreking van die hele, lywige werk bied nie. Dit ondersoek die uitgangspunte van haar filosofies-historiografiese metode aangesien dit haar bevindings bepaal.

\section{'n Filosofiese metode}

Gelukkig laat Allen die leser nie in die duister oor haar eie vertrekpunte nie. Sy beskou haar werk as filosofies van aard en ook as noodsaaklik, omdat die filosofie in onderskeiding van byvoorbeeld die teologie 'n eie perspektief op die probleem van die identiteit van die geslagte kan bied (vgl. Allen 1985:1). Filosofies ontbloot sy die 'fundamental structures of thought' of die basiese konsepte wat die vroukonsep bepaal.

Volgens haar gebruik die Filosofie slegs die menslike rede en observasie as middels (Allen 1985:1). Later (Allen 1985:5) word dit duideliker waarom dit die geval is wanneer Allen oor die verhouding tussen religie en filosofie handel. Allen (1985) maak 'n skeiding tussen die volgende twee gebiede om slegs op die filosofiese te konsentreer:

Arguments defended by an appeal to faith, to the scriptures, or to religious authorities ... have generally been excluded. On the other hand, arguments that appeal to the evidence of the senses, the reason, or to ancient philosophical authorities have been included. (bl. 5)

In hierdie aanhaling kom Allen se Katolieke oriëntasie duidelik na vore: Filosofie (op die natuurlike terrein) is iets neutraal-redeliks, terwyl slegs teologie (op die bonatuurlike terrein) met geloof en religie te make het.

Binne die reformatoriese tradisie is so ' $n$ dualistiese standpunt onaanvaarbaar. Allen het later self ook probleme ondervind om haar skeiding konsekwent deur te voer. Dit blyk byvoorbeeld duidelik uit haar analise van veral die Kerkvaders en die Middeleeuers, wie se filosofieë wel hulle teologieë beïnvloed het, maar terselfdertyd het hulle Christelike geloof omgekeerd ook 'n invloed op hulle filosofiese visies gehad. In plaas van die skeiding wat sy voorstaan, was daar in werklikheid 'n groot wisselwerking tussen filosofie en religie - selfs al by die Grieke.

\section{'n Feministiese benadering}

As feminis stel Allen die vroulike identiteit op die voorgrond. Sy behandel dus ook, anders as in die standaard filosofiehandboeke, verskillende vrouedenkers. Sy behoort egter duidelik tot 'n spesifieke nuanse in die feministiese denke. Allen (1985:5) skryf dat, terwyl akademiese filosowe binne die keuse tussen geslagtelike polariteit en eenheid gevange sit, die feministiese filosowe van haar tyd verstrik is in die dilemma van omgekeerde geslagtelike polariteit of eenheid waarvolgens nie mans nie, maar vroue die meerderwaardige geslag sou wees. Sy is dus nie ' $n$ voorstander van die vroeëre feministiese idee van geslagtelike polariteit nie, of ook nie van die latere feminisme wat geslagtelike verskille wou ontken nie. Sy is beslis ook nie 'n postmodernistiese feminis nie, want sy verkies geslagtelike komplementariteit, waar die verskillende geslagte mekaar behoort aan te vul.

\section{'n Ideëgeskiedenis}

Soos reeds gesê, gaan dit vir Allen oor 'n bepaalde konsep, naamlik dié van die vrou. Haar werk noem sy die eerste sistematiese studie in hierdie verband en dit handel oor 'how the concept of woman itself emerged, developed and influenced western philosophy' (Allen 1985:2). Hoewel 'n wisselwerking 
nie ontken kan word nie, wil dit lyk asof hierdie konsep die Westerse filosofie beïnvloed het, in plaas van die omgekeerde, naamlik dat die filosofie grondleggend was tot bepaalde geslagtelike konsepte.

'n Latere uitspraak (Allen 1985:7) bring groter duidelikheid oor die spesifieke historiografiese metode wat Allen volg. Konsepsuele geskiedenis beteken vir haar 'history of ideas'. Lovejoy (1952) was die vader van die wyse waarop die Westerse denkgeskiedenis weergegee is. 'n Bepaalde idee word beskryf soos wat dit deur die geskiedenis ontwikkel het.

'n Tyd lank was dit 'n gewilde metode, maar dit het later minder aanvaarbaar geword, veral omdat die verskillende idees deur Lovejoy en sy navolgers as min of meer in sigself geslote, outonome fenomene beskou is, geïsoleerd van die onderlinge verbande tussen allerlei ander konsepte. Allen (1985:7) moet haar metode ook verdedig teenoor destydse nuwere historiografiese metodes, wat meer sensitief wou wees vir die spesifieke histories-sosiale konteks van 'n denker. Sy hou egter vas aan 'n benadering waarin sy sistematies verskillende strukturele visies oor die vrou ondersoek om vas te stel hoe sekere denkpatrone dwarsdeur die geskiedenis voorgekom het.

Allen se ideëhistoriese aanpak is eerstens moontlik die oorsaak waarom sy nie voldoende aandag aan die ontiese en antropologiese grondslae van die verskillende visies op die vrou en haar verhouding tot die man gee nie. Die vroukonsep word as't ware uitgelig bo en tot 'n mate losgemaak van die fondamente waarop dit rus.

Tweedens lei die groter klem wat sy op die idee ('concept') van die vrou (eerder as op die geskiedenis) gee ook daartoe dat Allen nie voldoende aandag gee aan die belangrike normatiewe verskille tussen die tydperke waarin die verskillende denkers geleef en gedink het nie. Sy lig slegs die kontinuïteit van ' $n$ bepaalde tipe denkpatroon uit. Belangrike geestestromings - wat die verskillende visies op die vrou medebepaal het - word nie onderskei nie. 'n Voorbeeld hiervan is die duidelike religieuse rigtingsverskil tussen die pagane Griekse denkers en die Christelike kerkvaders en Middeleeuers - dit nog afgesien van die talle substromings by elkeen van hulle.

\section{Drie basiese idees}

Soos reeds genoem, ontbloot Allen (1985:3) die volgende drie grondliggende idees oor die verhouding tussen die geslagte dwarsdeur die 2000-jarige geskiedenis. Die eerste teorie is geslagtelike eenheid wat leer dat die twee geslagte gelyk is, omdat daar nie betekenisvolle verskille tussen hulle bestaan nie. (Hierdie is ' $n$ foutiewe redenasie, omdat gelykheid nie enersheid hoef te impliseer nie.) Tweede aan die beurt is die idee van geslagtelike polariteit, wat behels dat daar belangrike verskille tussen die geslagte is, met die (negatiewe) gevolg dat die manlike geslag meestal beter, hoër of meerderwaardig tot die vroulike gesien is. Derdens handel sy oor 'n geslagtelike komplementariteits-teorie, wat geleer het dat daar wel betekenisvolle verskille tussen die twee geslagte bestaan, maar dan met die (positiewe) doel om mekaar te kan aanvul.

Allen voeg na die eerste en die tweede teorie hierbo nog die volgende twee tussenposisies in. Geslagtelike neutraliteit sluit aan by teorie 1, maar met dié verskil dat dit die verskille tussen die man en die vrou as so onbenullig beskou dat hulle verontagsaam kan word om alleen op die eenheid toe te spits. Omgekeerde geslagtelike polariteit (in aansluiting by teorie 2) ontstaan eers later in die geskiedenis (in die sestiende eeu). Dit leer ook (soos teorie 2) dat die man en die vrou in belangrike opsigte verskil, maar kom dan (anders as in 2) tot die gevolgtrekking dat nie die man nie (soos in teorie 2), maar die vrou die meerderwaardige sou wees.

Die voor die hand liggende vraag is of hierdie drie (of vyf) modelle al die teoretiese moontlikhede wat die geskiedenis opgelewer het, uitput. Kan hulle nie ook maklik ontaard in ' $n$ keurslyf waarin ' $n$ veel ryker geskiedenis ingedwing word nie? Myns insiens het Allen met hierdie kategorieë volstaan, omdat sy op die moontlike verhoudings tussen die twee geslagte gefokus het - sonder om die verskillende, dieperliggende, antropologiese wortels, wat tot 'n groot verskeidenheid verhoudings kan lei, bloot te lê.

\section{Die grondliggende, antropologiese oorsake}

As filosoof besef Allen (1985:4) wel dat die verkeerde verhoudings (teorie 1 en teorie 2 hierbo) dieper antropologiese wortels moet hê. In albei gevalle is 'n verkeerde visie op die liggaamlike kant van die mens, volgens haar, egter die enigste oorsaak. Die eenheidsvisie devalueer volgens haar die liggaamlike, terwyl die polêre standpunt dit oorbeklemtoon.

Baie algemeen gestel, sou die digotomie (tweedeling) tussen siel en liggaam wel 'n deurlopende tema kon wees van die tydperk in die geskiedenis waaroor Allen se boek handel. Terselfdertyd bied hierdie periode van 2000 jaar verskeie verskillende standpunte oor hoe die denkers siel en liggaam en die verhouding daartussen beskou het. Een voorbeeld is dat nie net die visie op die liggaamlike nie, maar ook op die verskillende sielsdele 'n rol by die waardering van die vrou gespeel het. Die intellek is as die hoogste faset van die siel beskou. In hierdie geval was dit die manlik-gekwalifiseerde hoëre, redelike, universele siel wat gekontrasteer is met die vroulike, sogenaamde laere, individuele sielsemosies.

Lloyd (1984) se boek handel oor hierdie probleem. Sy skryf byvoorbeeld:

... our ideals of reason are in fact male ... ideals of Reason, far from transcending sexual difference, have helped to constitute it. That ideals of maleness have developed under the guise of supposedly neutral ideals of Reason has been to the disadvantage of women and men alike. (bl. 108-109)

'n Probleem met Allen se historiografie van die vrou-konsep is dus dat sy nie diep genoeg ingaan op die ontologiese en 
antropologiese wortels wat tot die verskillende teorieë oor die twee geslagte en hulle verhoudings gelei het nie. Eenvoudig gestel: Hoe 'n mens die mens man en vrou sien, bepaal uiteindelik ook hoe die verhouding tussen hulle beskou sal word. 'n Basiese ontiese probleem wat Allen nie hanteer het nie is byvoorbeeld dié van die eenheid en/of verskeidenheid van die werklikheid.

\section{Slegs verhoudings en hulle implikasies}

Dit gaan vir Allen primêr om die verskillende verhoudings tussen die geslagte: 'Is it a relation of hostility, of indifference, or of fulfilment?' (Allen 1985:9). Daar kan ook gevra word of 'n mens enige verhouding kan bepaal as jy nie eers duidelikheid het oor die aard van die twee entiteite wat jy in verhouding wil stel of wil vergelyk nie.

Afgesien van die drie basiese moontlike verhoudings wat sy onderskei, gebruik Allen by die beoordeling van elke denker nog drie addisionele kategorieë. Die eerste handel oor die rol wat die vader en moeder speel by die totstandkoming van hulle nageslag (d.w.s. die biologiese vlak). Die tweede handel oor hoe die vrou en die man beoordeel word ten opsigte van die wysheidsideaal (d.w.s. op intellektuele vlak) en ten derde of die twee geslagte tot dieselfde deugde in staat is of nie (d.w.s. op eties-morele vlak).

'n Mens sou egter kon opmerk dat hierdie drie kategorieë slegs die implikasies van die hoofteorieë oor die moontlike verhoudings tussen die man en die vrou uitspel. Die leser word dus nog verder weggevoer van die grondliggende ontologies-antropologiese grondslae. Waarom word soveel klem op die verhoudings gelê? Dit lei 'n mens (naas die eerste strukturele vraag: Wie is ek?) na die tweede fundamentele vraag waarop elke denker ' $n$ antwoord moet gee, naamlik: Hoe behoort ek te lewe? - ook in my verhouding met die ander geslag soos alreeds in 'Die twee basiese vrae' uiteengesit is.

Allen (1985:9) is ook in hierdie opsig eerlik teenoor haar lesers. Sy sien 'n ontwikkelingsgang in die Westerse denke. Aanvanklik het die antieke denkers die aard van die man en die vrou op 'n metafisiese wyse bepaal; vanaf die veertiende eeu is die klem op die teenstelling tussen die individuele karaktertrekke gelê; later het die klem na die mens as persoon verskuif; en vandag (die einde van die twintigste eeu) is die aksent op die verhouding tussen die geslagte geplaas.

Ten opsigte van die hedendaagse ontwikkeling sluit Allen waarskynlik by 'n meer irrasionalisties-relasionele beskouing aan. (Om op die diepere ontologies-antropologiese grondslae te fokus, sou volgens haar op 'metafisika' neerkom.) Verhoudings is vir haar die uitgangspunt of norm. Myns insiens impliseer dit subjektivisme (vgl. die bespreking onder 'groeiende subjektivisme'). Geen verhouding kan normatief in ditself wees nie, maar dit moet normatief beoordeel word.

Lloyd (1984:103-105) verskil ook hier van Allen. Sy stel dat die verskille tussen die twee geslagte nie as norme beskou moet word nie en sy sou dus heel waarskynlik dieselfde van verhoudings gedink het. Sy merk verder tereg ook op dat die vroulik-manlike onderskeid nie bloot 'n deskriptiewe klassifikasie is nie, maar 'n uitdrukking van 'n waardeoordeel. Dit kan volgens haar nie anders nie, omdat gesag en mag ook in die verhoudings ter sprake is.

\section{Geslagtelike aanvulling as maatstaf}

Allen is egter nie ' $n$ relativistiese postmodernis nie. Sy kies tussen die verskillende soorte verhoudings een as normatief. Hierdie verhouding is dié van komplementariteit. Volgens Allen (1985:5) bied hierdie standpunt ' $n$ oplossing vir die basiese probleem in die twee ander teorieë, naamlik óf die devaluasie, óf die oorbeklemtoning van die liggaamlik-materiële faset van menswees. Daarteenoor sou komplementariteit 'an integrated view of the place of materiality' bied.

Hoewel sy filosofie en geloof (teologie) probeer skei (vgl. "n Filosofiese metode'), kon sy nie die versoeking weerstaan om tog by te voeg dat dit nie toevallig is dat die Christelike denkers wat sy hanteer, die eerste is wat die teorie van komplementariteit verdedig het nie. Die rede is dat hierdie model volledig ooreenstem met die fundamentele Christelike teologiese oortuigings in die (goddelike) skepping van die mens en die opstanding van die liggaam. (Sy aanvaar blykbaar 'n digotomie van siel en liggaam - sonder om laasgenoemde as minderwaardig te beskou.)

Allen se voorkeur vir hierdie spesifieke verhouding bepaal haar interpretasie van die geskiedenis. Die leser se aandag word herhaaldelik gevestig op haar uitverkore model, naamlik Hildegard van Bingen (1098-1179).

\section{Die betekenis van komplementariteit}

'n Aanvullingsteorie kan op verskillende maniere verstaan word, naamlik die man moet die vrou aanvul (omdat sy slegs 'n halfmens sou wees), óf die omgekeerde (omdat die man 'n onvolledige mens sou wees), óf hulle moet mekaar wedersyds aanvul (omdat altwee geslagte gebrekkige mense sou wees). Kan 'n mens egter beweer dat vrou-/manwees onvolledigheid beteken? Indien nie, berus die hele idee van komplementariteit dan nie op valse vooronderstellings nie?

Lloyd (1984) is bewus van die gevaar indien vroue byvoorbeeld mans moet komplementeer:

Making good the lack in male consciousness, providing it with a necessary complementation by the 'feminine', is a large part of what the suppression and the correlative constitution of 'womankind' has been all about. (bl. 105)

Om vas te stel wat presies Allen onder die komplementariteitsmodel verstaan, is dit nodig om na te gaan hoe Hildegard van Bingen oor die verhouding tussen die geslagte gedink het. In die volgende afdeling word dus eers na Allen se analise van Hildegard se standpunt gekyk en daarna na enkele ander figure. Hierdie afdeling dien terselfdertyd ook as 'n toets om vas te stel of Allen se onderskeid tussen 
die drie hooftipe verhoudings in ooreenstemming is met die werklike standpunte van die betrokke filosowe uit die geskiedenis.

\section{'n Steekproef uit die geskiedenis}

Hildegard se standpunt (komplementariteit), asook dié van twee belangrike vroeëre Griekse filosowe, naamlik Plato (volgens Allen 'n voorstander van die eenheidsvisie) en Aristoteles (wat 'n polariteit tussen die geslagte voorstaan), word ondersoek. Verder word ook gelet op die bekende Christelike Middeleeuse denker Thomas van Aquino, wat eers ná Hildegard op die toneel verskyn het.

\section{Hildegard van Bingen (1098-1179 n.C.)}

Vir meer gegewens oor die lewe en werk van hierdie belangrike mistieke vrouedenker uit die geskiedenis word die belangstellende leser verwys na Bownie en Oliver (1996), Butcher (2007) en McGinn en McGinn (2003:97-113).

Reeds aan die begin van haar uiteensetting wil dit lyk asof Allen nie sonder enige moeite Hildegard se standpunt as komplementariteit kan tipeer nie. Sy (Allen 1985:295) erken dat Hildegard se teorie oor geslagtelike identiteit nie konsistent is nie. Soms is daar aanduidings dat Hildegard 'n soort paradoksale visie huldig van sowel geslagtelike polariteit as omgekeerde polariteit. Sy beskou die vrou op die natuurlike vlak as die swakker geslag, maar op die vlak van die genade as voortrefliker as ' $n$ man.

Soos reeds voorheen gesuggereer, is Allen as Christen nie meer in staat om haar voorneme, naamlik om net filosofies (op natuurlike wyse) oor die vrou te handel, konsekwent deur te voer nie. By Hildegard is die filosofiese (op die gebied van die natuur) en die teologiese (op die bonatuurlike terrein) te nóú verweef.

Omdat Allen self (as Katolieke denker) die natuur-genade onderskeid aanvaar, maak sy (Allen 1985) die volgende onoortuigende stelling: 'However, Hildegard balances her intermittent references to this paradox with a thorough and farreaching defence of the equality and significant differentiation of woman and man' (bl. 293).

In die daaropvolgende skematiese samevatting maak Allen 'n onderskeid tussen Hildegard se visie op geslagtelike komplementariteit in die hemel en op die aarde. Die twee kon egter nie waterdig van mekaar geskei word nie, want God is ook in die geval van die veronderstelde komplementariteit op die gebied van die wêreld (natuur) betrokke. Hy verskaf die menslike siel aan albei geslagte, wat daarom albei sy beeld vertoon.

In die hemel kan daar egter nog groter komplementariteit wees, aangesien die twee geslagte by die opstanding verskillend maar tog gelyk sal wees en dieselfde sal ook gebeur in die geval van vroulike sowel as manlike heiliges.
Die artikelouteur se indruk is dat Hildegard slegs op die bonatuurlike genadevlak van die teologie werklike komplementariteit leer, terwyl sy op die natuurlik-filosofiese vlak na 'n polariteitsteorie neig. Eers in die hiernamaals sal mans en vroue nie net anders nie, maar ook eenders (gelyk) wees.

Later (vgl. Allen 1985:297, 298, 309) word dit egter duideliker waarom Allen van mening is dat Hildegard 'n komplementariteitsteorie huldig. God is vir haar sowel manlik as vroulik en mense reflekteer in hulle siele hierdie biseksuele aard van God. God se manlike trekke is dapperheid en krag en sy vroulike is barmhartigheid en genade. Om volledige mens te wees, is albei trekke nodig. Mans moet dus by hulle natuurlike trekke (dapperheid en krag) begin en die twee vroulike trekke ontwikkel. Vroue behoort die omgekeerde te doen.

Dit stem ooreen met wat reeds hierbo ('Geslagtelike aanvulling as maatstaf') vermoed is, naamlik dat die komplementariteitsmodel onvolledigheid by een of albei van die twee geslagte veronderstel. Volgens Hildegard is sowel die man as die vrou gebrekkige mense en het dus wedersyds 'n aanvulling vanuit die ander geslag nodig om volledig mens te kan wees.

Soos voorheen genoem, is Allen van mening dat die geringskatting of oorskatting van die liggaam die hoofoorsake was van die verkeerde visies op geslagtelikheid. Allen skryf Hildegard se nuwe, oorspronklike teorie van komplementariteit toe aan die feit dat sy siel en liggaam volkome geïntegreer het. Die artikelouteur weet egter nie hoe sy hierdie gevolgtrekking kon maak nie, aangesien Hildegard leer (vgl. Allen 1985:299) dat die saad wat van die man af kom, deur die vrou verwarm word, waarna God 'n siel in die embrio inplant. (Dit is die bekende kreasianistiese teorie.) Syns insiens bly dit 'n digotomistiese en dus 'n niegeïntegreerde mensbeeld.

'n Stap terug in die geskiedenis bied dalk verheldering hieroor.

\section{Plato (428-355 v.C.)}

Plato word hier ondersoek aangesien hy volgens Allen die vader is van die teorie van geslagtelike eenheid. In haar skematiese oorsig van Plato se denke (Allen 1985:58) sien sy egter ' $n$ onderskeid tussen Plato se denke op die kosmiese vlak, waar hy geslagtelike polariteit voorstaan en die wêreldse vlak, waar geslagtelike eenheid heers. Die outeur vermoed dat Allen met kosmiese vlak die oog het op Plato se ideëleer (in 'n afsonderlike wêreld) waarvandaan die menslike siele ook sou kom.

Plato huldig volgens Allen (1985:80) duidelik 'n siel-liggaam dualisme. Vanuit hulle (geslaglose) siele beskou, is die twee geslagte gelyk; maar vanuit hulle liggame gesien, is die vrou die minderwaardige een. (Om in 'n vrou gereïnkarneer te word, beskou Plato as die straf vir 'n vroeëre immorele, 
lafhartige manlike siel.) Plato devalueer die materiële wêreld (teenoor die wêreld van idees) in die algemeen en veral die menslike liggaam (vgl. Allen 1985:68-70).

Wanneer Allen Plato se deugdeleer in oënskou neem, kom Plato se antropologie effens duideliker na vore. Plato onderskei (behalwe die liggaam) drie dele in die menslike siel, naamlik die rede, die wil en die begeertes. 'n Mens sou hierdie indeling klassiek kon noem, want dit kom daarna by talle denkers - ook Christene - dwarsdeur die geskiedenis na vore, dikwels ook as die onderskeid tussen die hoof, die hand en die hart. Vander Stelt (2005) behandel hierdie soort antropologie in besonderhede en Lloyd (1984:7-11) wys ook daarop by Plato en die Griekse denke in die algemeen.

'n Hoër-laerverdeling van menslike sielsvermoëns lei gewoonlik tot 'n geringskatting van die laere. Die minderwaardige posisie by die vrou kan dan nie net aan die onderwaardering van die liggaam toegeskryf word nie (Allen se hipotese), maar ook aan die feit dat die manlike geslag se siele met die rede en die wil vereenselwig word en die vroue s'n met begeertes en gevoelens. Net soos Hildegard nie vir die outeur oortuigend net komplementariteit voorstaan nie, kan Plato syns insiens ook nie as die grondlegger van 'n eksplisiete eenheidsmodel beskou word nie.

\section{Aristoteles (384-322 v.C.)}

In teenstelling met die twee voorafgaande denkers is Allen (1985:83 e.v.) se beskrywing van Aristoteles se filosofie, wat ten grondslag van sy visie oor die man-vrouverhouding lê, die duidelikste. Hy huldig 'n hiërargiese ontologie wat vanaf die hoogste syn (die goddelike) afloop na die laagste (suiwer materie). Alles bestaan uit vorm (die aktuele en universele) en materie (die potensiële en individuele). Die vorm is die belangrikste. Materie is 'n gebrek aan vorm.

Hoewel die man en die vrou uit vorm (siel) en materie (liggaam) saamgestel is, word die vrou met die materiële geassosieer. By konsepsie kom die siel dus van die man en die liggaam van die vrou.

Ook Aristoteles onderskei die genoemde drie sielsdele, naamlik die rasionele, die sensitiewe en die vegetatiewe. Terwyl die man oor die hoëre, goddelike, intellektiewe sielsvermoë beskik, het die vrou net aan die laere emosionele of irrasionele deel. Op grond hiervan het Aristoteles sy bekende neerhalende uitsprake oor die vroulike geslag gemaak. Hy beweer dat vroue misvormde mans is, 'n gebrek aan manlikheid het, irrasioneel, onderdanig en beperk is tot die private lewe (vgl. Allen 1985:121). Aristoteles skryf (vgl. Allen 1985:118) dat die man 'n perfekte mens is, terwyl vroue maklik huil, jaloers en klaerig is, geneig is om te skel en moedeloos te wees, sonder skaamte en selfrespek is, leuenagtig en vals is, traer om tot aksie oor te gaan en hulle het ook minder kos nodig. Allen tipeer Aristoteles myns insiens korrek, naamlik daar kan geen twyfel bestaan dat hy 'n polêre verhouding tussen die geslagte voorgestaan het nie.

\section{Thomas van Aquino (1224/1225-1275)}

Het hierdie bekende Christelike Middeleeuse denker dalk die vroulike geslag hoër geag? Ongelukkig nie. Allen (1985:410) merk tereg op dat 'n belangrike rede daarvoor was dat Thomas besluit het om Aristoteles se filosofie as grondslag vir sy Christelike teologie te gebruik. (Hoewel Allen poog om 'n duidelike skeiding tussen filosofie en teologie te maak [vgl. vroeër in hierdie artikel] staan sy hier nie so krities teenoor Thomas se vermenging van die twee dissiplines nie.)

Thomas was 'n sintesedenker. Soos duidelik uit Allen (1985:387 e.v.) se bespreking blyk, het hy met sy natuurgenademetode die akkommodasie tussen die pagane filosofie van Aristoteles en die Christelike geloof bewerk. Op die terrein van die natuur was Aristoteles se denke die norm en op die terrein van die genade is die gesag van die Bybel aanvaar.

Thomas huldig dus 'n dubbelvisie op die vrou. Op die terrein van die natuur aanvaar hy Aristoteles se minagting van die vrou en huldig dus 'n geslagtelike polêre standpunt. (Die vrou is volgens Thomas 'n onegte, baster man, die geboorte van dogters is 'n ongeluk, die vroulike geslag is onvolmaak teenoor die manlike, ens.) Hier vind ' $n$ mens weer dieselfde hiërargiese ontologie terug, naamlik hoe nader aan God, hoe meer manlik is die mens. Die goddelike word met die rasionele sielsdeel, wat die manlike geslag tipeer, verbind, terwyl vroulikheid met die laere sielsdele (die sensitiewe en vegetatiewe) geassosieer word.

Op die terrein van die bonatuurlike genade lyk die prentjie egter heeltemal anders, omdat Thomas hier nie na Aristoteles nie, maar na die Bybel wou luister. Allen (1985:386; vgl. ook haar skematiese voorstelling hier) praat op hierdie terrein selfs van komplementariteit by Thomas, omdat hy leer dat op hierdie vlak albei geslagte toegang tot goddelike wysheid en teologiese deugde het en ook eendag in die opstanding van die liggaam sal deel.

Hierdie bonatuurlike troosprys geld natuurlik slegs indien 'n mens, soos Thomas, die werklikheid dualisties in natuurlikebonatuurlike terreine verdeel. Dit is egter nie 'n Bybelse standpunt nie. God se Woord verwerp uitdruklik hierdie oorspronklik pagane tweedeling in die skepping. Volgens die Skrif is God se genade sy gunsbetoon aan 'n gebroke skepping - iets wat eers ná die sondeval van die mens nodig was. Die teenoorgestelde van genade is God se toorn en straf vir die oortreding van sy verordeninge of riglyne vir die mens se lewe. In die geval van die mens is vergewe sondes (genade) die teenoorgestelde van sondes wat nie bely en vergewe is nie. Dit gaan in die Skrif dus om twee verskillende religieuse rigtings en nie om 'n ontiese tweedeling in die skepping self nie. In so 'n ontiese tweedeling sou genade en natuur (skepping) bo of langs mekaar gestel kon word. God se genade vervolmaak nie bloot die natuur nie, maar herskep dit sodat dit weer goed kan wees. 


\section{Terugskouende evaluering}

Allen het ongetwyfeld ' $n$ groot bydrae gelewer tot ' $n$ beter verstaan van die begrip vrou in die loop van die eerste 2000 jaar van die Westerse filosofiese denke. In die voorafgaande bespreking daarvan is ook heelwat kritiese kommentaar op haar werk gelewer. Dit hoef nie weer hier herhaal te word nie. Die twee belangrike vrae waarmee die betoog begin is, vereis egter nog aandag. Die eerste was die strukturele vraag, naamlik Wie is ek as man of vrou? Die tweede was die normatiewe vraag: Hoe behoort ek as vrou of man te lewe? Anders gestel: Hoe sien 'n mens die vrou en die man onties gestruktureerd (eerste vraag) en hoe behoort die normatiewe rigting in hulle onderlinge verhoudings tot uitdrukking te kom (tweede vraag)? Tot hoe 'n mate het Allen hierdie twee basiese lewensvrae bevredigend beantwoord?

\section{Die struktureel-antropologiese grondslae}

Menswees bestaan nie geïsoleerd van die res van die kosmos nie. 'n Mens se visie op die skepping in die algemeen bepaal ook jou siening van die mens. Hoe die mens beskou word, is weer van beslissende betekenis vir iemand se perspektief op man- en vrouwees. Die aangewese weg is dus van ontologie na antropologie na geslagtelikheid.

Allen is egter geneig om die omgekeerde pad te volg. Dit is nie noodwendig ' $n$ verkeerde metode nie, maar die antropologiese en ontologiese grondslae van die verskillende visies op geslagtelikheid en ook die verhouding tussen die twee geslagte moet dan duidelik opgediep word. Soos aangetoon, slaag sy nie te goed hierin nie.

Die digotomistiese mensbeskouing (in die vorm van 'n subsustensieteorie, wat 'n deur God ingeskape en onsterflik voortbestaande siel na die dood huldig) wat Allen toegedaan is, stel haar nie in staat om grondiger kritiek op die antropologieë van die denkers wat sy bespreek, te bied nie. Volgens so 'n mensvisie bestaan die mens slegs uit twee dele, naamlik siel en liggaam. Soos verduidelik, kan die siel verder (van hoër na laer) in intellektiewe, sensitiewe en vegetatiewe dele verdeel word. Hierteenoor verwerp die reformatoriese filosofie 'n digotomie van siel en liggaam (vgl. Van der Walt 2010:259 e.v.). Verder onderskei dit ook 15 fasette of modaliteite by die mens. Nie een van hierdie kante van menswees is belangriker of hoër as die ander nie, of is net tipies van die man- of die vrouwees nie.

\section{Die normatiewe rigting}

In die voorafgaande uiteensetting het die normatiewe vraag telkens na vore gekom. Stel God die norm deurdat Hy die vrou op ' $n$ bepaalde wyse geskep het, of is die man die norm, aan wie se gesag die vrou onderdanig moet wees? Is dit dalk die menslike biologie (liggaam) wat vroue normeer? Is die norm die heersende kultuur waaraan die vrou nie kan ontsnap nie? Moet 'n mens dalk die postmodernistiese standpunt aanvaar, waarvolgens elke vrou haar eie vroulike identiteit konstrueer, maar wat dan tot normatiewe relativisme lei?
Allen is hieroor nie baie duidelik nie hoewel sy ten minste sê dat sy nie laasgenoemde opsie oorweeg nie. Sy probeer die probleem oplos deur nie op die manlike en die vroulike identiteit as mense te fokus nie, maar wel op hulle verhouding. Menslike verhoudings word dus haar norm. Soos aangetoon, is so 'n standpunt egter problematies, omdat 'n verhouding afhanklik is van wie diegene is wat in 'n verhouding staan. (Hoewel dit nog nie 'n norm bied nie, kan die struktureelontiese vraag dus nie vermy word nie.)

Tussen die vyf moontlike verhoudings wat sy onderskei, val Allen se eie keuse op die komplementariteitsverhouding as norm. Dit lewer egter (soos reeds getoon) verdere komplikasies op sonder om werklik by 'n duidelike normatiewe riglyn uit te kom.

'n Belangrike vraag is byvoorbeeld watter tipe verhoudings Allen in gedagte het. Tot ' $n$ mate beantwoord sy (vgl. 'Slegs verhoudings en hulle implikasies') wel die vraag deur drie soorte verhoudings as kriteria te gebruik, naamlik die biologiese (by voortplanting), die logiese en die etiese of morele. Sy hanteer egter nie die volgende moontlike verhoudings nie, naamlik godsdienstige, estetiese, juridiese, politieke, sosiale, ekonomiese, beroeps, linguale, psigiese, fisiese en ruimtelike verhoudings. Dit is alles eiesoortige verhoudings wat aan unieke norme moet beantwoord. Verhoudings tussen die man en die vrou in die huwelik, die gesin, die kerk, die bedryf en die staat is tog nie dieselfde nie - net soos die gesagsverhoudings in elkeen van hierdie samelewingsverbande anders gekwalifiseerd is.

\section{Afsluiting: Voortgesette nadenke is nodig}

Ter afsluiting word die aandag op twee sake gevestig. Eerstens word kortliks genoem hoe ander kontemporêre Christelike denkers oor hierdie vraagstuk dink. Tweedens word daarop gewys dat Vollenhoven (die bekende Christelike denker) se probleem-historiese metode beter daarin slaag om die ontologiese en antropologiese vooronderstellings bloot te lê wat ten grondslag van die verskillende visies op die mens is.

\section{Verdere besinning}

In Christelike kringe duur die soektog na die unieke van die vrou en die man ook voort, sowel as die maatstaf wat hulle onderlinge verhoudings behoort te bepaal. Hier volg ten slotte 'n paar voorbeelde met die oog op verdere besinning.

Die versamelwerk onder redaksie van Van Leeuwen (1993) bepleit gelykheid en wederkerigheid (mutuality) tussen die twee geslagte, wat dan as norm vir alle verhoudings moet geld. Op talle plekke in die versamelwerk word betoog dat shalom God se wil op hierdie gebied is. Die vraag is egter of vrede nie eerder die gevolg van gehoorsaamheid aan God se norme is nie.

Ook Olthuis (1997:245) se oplossing is wederkerigheid (soos ook dié van Susan Bouwer s.a.:8). Volgens Olthuis is God se 
skepping vol verskille en is dit goed gemaak. Die mens kan dit reg gebruik (dit erken en daaroor bly wees) of verkeerd (dit as gebreke of teenoorgesteldes beskou). Die verskille tussen die twee geslagte beteken volgens Olthuis dus nóg distansie (polariteit), nóg fusie (eenheid), nóg dominasie, nóg om gedomineer te word. Wederkerigheid beteken volgens hom ook nie dieselfde as Allen se komplementariteit, waarvolgens die ander vir my of ek die ander moet aanvul nie. Olthuis beroep hom op die dubbele liefdesgebod in die Skrif ('Jy moet jou naaste liefhê soos jouself') as norm. In wederkerigheid moet liefde sonder voorwaarde gegee en ontvang word.

Verkerk (1997:209 e.v.) beskou geslagtelikheid as een van die baie antwoorde wat die mens as die skepsel aan God gee. (Dit is dus ' $n$ verantwoordelike taak en nie bloot 'n kulturele produk nie.) In hierdie antwoord aan God is die twee geslagte wedersyds van mekaar afhanklik en op mekaar betrokke. Dit lyk dus baie na aan Olthuis se standpunt.

Ten slotte word daarop gewys dat Storkey (2001:129-131) in die lig van die Skrif (sy verwys ter stawing na talle Bybeltekste) vier paradigmas vir die verhouding van die geslagte onderskei, naamlik verskil (difference), enersheid (sameness/similarity), komplementariteit en eenheid (unity).

Storkey (2001) is egter bewus van die misverstande wat aan hierdie vier konsepte kan kleef en stel duidelik wat sy onder elkeen verstaan. Verder vestig sy die aandag daarop dat aan al vier hierdie Bybelse temas tegelyk aandag gegee moet word. Indien dit nie so gebeur nie, word die vier Bybelse riglyne verdraai. (Eensydige klem op eenheid, kan byvoorbeeld maklik tot enersheid lei, terwyl alle aandag op verskeidenheid verkeerdelik as geskeidenheid verstaan kan word.) Sáám bied hierdie temas egter die volle Bybelse openbaring en ruimte om aan die verhouding tussen die twee geslagte in gehoorsaamheid en op 'n kreatiewe wyse gestalte te gee.

\section{'n Noodsaaklike opvolg}

Dit is duidelik dat daar nie met hierdie artikel volstaan kan word nie. 'n Opvolgartikel sal dus ondersoek in watter mate Vollenhoven lig op die antropologiese en normatiewe vrae kon werp wat hier na vore gekom het. Alhoewel hy, soos Dooyeweerd, hom nie met hierdie probleme bemoei het nie, hou die resultate van sy navorsing wel belangrike implikasies in wat meer eksplisiet uitgespel kan word.

\section{Erkenning \\ Mededingende belange}

Die outeur verklaar dat hy geen finansiële of persoonlike verbintenis het met enige party wat hom nadelig of voordelig kon beïnvloed in die skryf van hierdie artikel nie.

\section{Literatuurverwysings}

Ackerman, D.M., 1998, 'Feminist and womanist hermeneutics', in S. Maimela \& A. König (eds.), Initiation in theology, pp. 349-358, Van Schaik, Pretoria.
Allen, P., 1985, The concept of woman: The Aristotelian revolution 750 BC-AD 1250, William. B. Eerdmans Publishing Company, Grand Rapids.

Allen, P., 2002, The concept of woman: Early humanist reformation, 1250-1500, William. B. Eerdmans Publishing Company, Grand Rapids.

Bouwer, S., s.a., Imaging God as woman and man together: A study of Genesis 2, Institute for Christian Studies, Toronto.

Bownie, F. \& Oliver, D. (eds.), 1996, Hildegard of Bingen: An anthology, SPCK, London. Buijtendijk, F.J.J., 1975, De vrouw: Haar natuur, verschijning en bestaan - Een existentieel-psychologische studie, Spectrum, Utrecht.

Butcher, C.A. (ed.), 2007, Hildegard of Bingen: A spiritual reader, Paraclete Press, Brewster.

Chanter, T., 2006, Gender: Key concepts in philosophy, Continuum International, London.

De Beauvoir, S., 1962, The prime of life, Penquin, Harmondsworth.

De Beauvoir, S., 1964, Nature of the second sex, Four Square Books, London.

De Beauvoir, S., 1965, Memoirs of a dutiful daughter, Penquin Books, Harmondsworth.

James, S., 2005, 'Feminism', in E. Craig (ed.), The shorter Routledge Encyclopedia of Philosophy, Routledge, London, pp. 268-275.

Keane, M.-H., 1998, 'Feminist and womanist theology', in S. Maimela \& A. König (eds.), Initiation in theology, pp. 121-136, Van Schaik, Pretoria.

Kuyper, A., [1913] 1932, De erepositie der vrouw, Kok, Kampen.

Landman, C., 1984, 'A profile of feminist theology', in W.S. Vorster (ed.), Sexism and feminism, pp. 1-29, University of South Africa Press, Pretoria.

Landman, C., 1998, 'African women's theology', in S. Maimela \& A. König (eds.), Initiation in theology, pp. 127-140, Van Schaik, Pretoria.

Lloyd, G., 1984, The man of reason: 'Male' and female in western philosophy, Methuen, London. http://dx.doi.org/10.4324/9780203423240

Lovejoy, A.O., 1952, Essays in the history of ideas, Johns Hopkins University Press, Baltimore.

McGinn, B. \& McGinn, P.F. (eds.), 2003, Early Christian mystics, The Crossaway Publications, New York.

Olthuis, J.H., 1997, 'Crossing the threshold: Sojourning together in the wild spaces of love', in J.H. Olthuis (ed.), Knowing other-wise, pp. 235-258, Fordham University Press, New York.

Olthuis, J.H., 2005, 'The miracle of mutual love: Luce Irigaray and the ethics of sexual difference', in J.H. Kok (ed.), Ways of knowing in concert, pp. 71-84, Dordt College Press, Sioux Center.

Sewell, A., 2011, 'Sexuality and gender', in A. Sewell (ed.), Calvin and the body: An enquiry into his anthropology, pp. 173-190, VU-Press, Amsterdam.

Storkey, E., 1995, 'Dooyeweerd's anthropology: The male-female dimension', in S. Griffioen \& B.M. Balk (eds.), Christian philosophy at the close of the twentieth century, pp. 85-92, Kok, Kampen.

Storkey, E., 2001, Origins of difference: The gender debate revisited, Baker Academic, Grand Rapids.

Van der Walt, B.J. (red.), 1987, Venster op die vrou: Reformatoriese perspektiewe, Instituut vir Reformatoriese Studie, Potchefstroom.

Van der Walt, B.J., 2006a, 'A liberating perspective to women in Africa', in B.J. van der Walt (ed.), When African and western cultures meet, pp. 228-316, The Institute for Contemporary Christianity in Africa, Potchefstroom.

Van der Walt, B.J., 2006b, 'Wat dit beteken om vrou (of man) te wees', Die Kerkblad 108(3185), 30-32.

Van der Walt, B.J., 2006c, 'Die vrou in die ampte in die Gereformeerde Kerk SA', Die Gereformeerde Vroueblad 60(10), 5-8.

Van der Walt, B.J., 2006d, 'Die vrou in die ampte in die Gereformeerde Kerk SA', Die Gereformeerde Vroueblad 60(11), 7-11.

Van der Walt, B.J., 2010, 'The biblical perspective on being human', in B.J. van der Walt (ed.), At home in God's world, pp. 259-289, The Institute for Contemporary Christianity in Africa, Potchefstroom.

Van der Walt, B.J., 2011, 'Women and marriage in the Middle Ages, in Calvin and in our own time', in S. Bishop (ed.), Like the first gleam of dawn: Reformational studies, pp. 72-125, The Institute for Contemporary Christianity in Africa, Potchefstroom.

Van Leeuwen, M.S., 1990, Gender and grace, InterVarsity Press, Downers Grove.

Van Leeuwen, M.S. (ed.), 1993, After Eden: Facing the challenge of gender reconciliation, William. B. Eerdmans Publishing Company, Grand Rapids.

Van Leeuwen, M.S., 2013, 'Abraham Kuyper and the cult of true womanhood: An analysis of De erepositie der Vrouw', in S. Bishop \& J.H. Kok (eds.), On Kuyper: A collection of readings on the life, work and legacy of Abraham Kuyper, pp. 423442, Dordt College Press, Sioux Center.

Vander Stelt, J.C., 2005, “"Faculty psychology” and theology', in J.H. Kok (ed.), Ways of knowing in concert, pp. 45-60, Dordt College Press, Sioux Center.

Verkerk, M.J., 1997, Sekse als antwoord, Buijten \& Schipperheijn, Amsterdam.

Wesselius, J.C., 1997, 'Points of convergence between Dooyeweerdian and feminist views of the philosophic self', in J.H. Olthuis (ed.), Knowing other-wise: Philosophy on the threshold of spirituality, pp. 54-68, Fordham University, New York. 